\title{
Dampak input (tenaga kerja) dan output (GDP) sektor pertanian terhadap konsumsi pemerintah di Indonesia
}

\author{
Rahma Nurjanah*; Erni Achmad \\ Prodi Ekonomi Pembangunan Fakultas Ekonomi dan Bisnis Universitas Jambi \\ *E-Mail korespodensi: rahma_nurjanah@unja.ac.id
}

\begin{abstract}
This study aims to analyze the development of inputs (labor) and output (GDP) in the agricultural sector and government consumption in Indonesia during the period 1993 2014 and analyze the impact of inputs (labor) and output (GDP) on the agricultural sector on government consumption in Indonesia. The result of the research show during period from 1993-2014 output GDP in agriculture sector is 17\% with an average value is 496,9 trillion rupiah. For agricultural sector workers the average value of growth is equal to $-0.007 \%$, with an average value of 39,621.18 thousand people, the highest growth occurred in 1998 which amounted to $13.29 \%$ and the lowest growth occurred in 1997 which was equal to $-7.76 \%$. The regression results show that the GDP variable Output of the agricultural sector has a positive and significant effect on government consumption, while the agricultural sector labor variable has no significant effect on government consumption.
\end{abstract}

Keywords: Agricultural Sector GDP, Government Consumption, Agricultural Sector Labor

\begin{abstract}
Abstrak
Penelitian ini bertujuan untuk menganalisis perkembangan input (tenaga kerja) dan Output (GDP) sektor pertanian dan konsumsi pemerintah di indonesia selama periode tahun 1993-2014 dan menganalisis dampak input (tenaga kerja) dan output (GDP) sektor pertanian tersebut terhadap Konsumsi pemerintah di Indonesia. Hasil penelitian menunjukkan selama periode tahun 1993-2014 output GDP sektor pertanian adalah $17 \%$ dengan nilai rata-ratanya adalah 496,9 triliun rupiah. Untuk tenaga kerja sektor pertanian nilai rata-rata pertumbuhannya yakni sebesar $-0.007 \%$, dengan nilai rata-rata sebesar 39.621,18 ribu orang, pertumbuhan tertinggi terjadi pada tahun 1998 yakni sebesar 13,29\% dan pertumbuhan terendah terjadi pada tahun 1997 yakni sebesar $7.76 \%$. Hasil regresi menunjukkan bahwa variabel GDP Output sektor pertanian berpengaruh positif dan signifikan terhadap Konsumsi pemerintah, sementara variabel tenaga kerja sektor pertanian tidak berpengaruh signifikan terhadap konsumsi pemerintah.
\end{abstract}

Kata kunci: GDP sektor pertanian, Konsumsi pemerintah,Tenaga kerja sektor pertanian

\section{PENDAHULUAN}

Indonesia adalah Negara yang kaya akan sumber daya alam baik sumber daya alam yang dapat diperbarui dan sumber daya alam yang tidak dapat diperbarui, dengan potensi sumber daya alam tersebutlah terutama sumber daya alam yang dapat diperbaharui seperti sektor pertanian Indonesia menjadi salah satu Negara yang menghasilkan berbagai macam output pertanian yang di ekspor ke luar negeri seperti karet,kelapa sawit,kopi,teh dan lainnya selain itu potensi tersebut juga tercermin dari sumbangan sektor pertanian masih relatif tinggi pada tahun 2013 nilai sektor pertanian 
sebesar 1.083,1 Triliun rupiah dari total GDP Indonesia sebesar 8.158,2 Triliun Rupiah (Sumber ADB) dan Jumlah tenaga kerja yang bekerja di sektor ini yang paling banyak dengan data menunjukkan pada tahun 2013 jumlah tenaga kerja yang bekerja di sektor pertanian adalah 39,220 dalam ribuan jiwa sehingga diharapkan sektor pertanian ini dapat memberikan kontribusi terhadap pendapatan nasional. Dengan pendapatan nasional yang semakin meningkat maka dengan demikian sumber pemerintah dalam pengeluaran termasuk dalamnya konsumsi pemerintah dapat dibiayai dari pendapatan nasional. Dengan potensi sektor pertanian termasuk didalamnya input dan outputnya dapat memberikan kontribusi kepada peningkatan pendapatan nasional sehingga dapat membiayai pengeluaran konsumsi pemerintah.

Berdasarkan uraian pada latar belakang diatas yang melatar belakangi penulis untuk menganalisis GDP sektor pertanian dan dampaknya terhadap pembangunan ekonomi (Mengurangi kemiskinan dan Pengangguran). Secara spesifik perumusan permasalahan penilitian ini adalah sebagai bagaimanakah perkembangan Input (Tenaga kerja) dan output (GDP) sektor pertanian, dan konsumsi pemerintah di Indonesia selama periode tahun 1993 - 2014. Selanjutnya bagaimana pengaruh input (Tenaga kerja) dan output (GDP) Sektor pertanian terhadap Konsumsi pemerintah di Indonesia selama periode tahun $1993-2014$.

\section{METODE}

Dalam menganalisa data-data yang diperoleh untuk menjawab tujuan dari penelitian ini, maka digunakan metode-metode analisa sebagai berikut:

1. Analisis Deskriptif

Merupakan analisis yang dilakukan secara deskriptif untuk memberikan gambaran mengenai perkembangan Variabel-variabel Penelitian, digunakan rumus:

Igt $=\frac{\text { It }- \text { It }-1}{\text { It }-1} \times 100 \%$

Dimana:

$\overline{\text { Igt }}=$ Perkembangan Variabel-variabel Penelitian (Tenaga kerja dan GDP sektor pertanian, Konsumsi Pemerintah)

It $=$ Variabel Penelitian tahun $\mathrm{t}$

It-1 = Variabel Penelitian tahun t-1

2. Analisis Kuantitatif

Kemudian untuk menganalisis pengaruh Input (Tenaga kerja) sektor pertanian terhadap Konsumsi Pemerintah Indonesia digunakan regresi sederhana (Gujarati) sebagai berikut:

$\mathbf{G}=\boldsymbol{\beta} \mathbf{0}+\boldsymbol{\beta}_{1} \mathbf{L}+\mathbf{e}$

$\mathrm{G} \quad=$ Konsumsi Pemerintah

Bo $\quad=$ Konstanta

$\beta \mathrm{i}=$ Koefisien regresi

$\mathrm{L}=$ = Tenaga Kerja sektor pertanian

$\mathrm{e}=$ error disturbance

$\mathbf{G}=\boldsymbol{\beta O}_{0}+\boldsymbol{\beta}_{1} \mathbf{Y}+\mathbf{e}$

Dimana:

$\mathrm{Y}=$ GDP sektor pertanian

ßo $\quad=$ Konstanta

$\beta \mathrm{i}=$ Koefisien regresi

$\mathrm{G}=$ Konsumsi Pemerintah

$\mathrm{e}=$ error disturbance 


\section{HASIL DAN PEMBAHASAN}

\section{Perkembangan GDP output sektor pertanian Indonesia}

Untuk mengetahui perkembangan GDP Output sektor pertanian di Indonesia selama periode tahun 1993 - 2014 dapat dilihat pada tabel berikut ini :

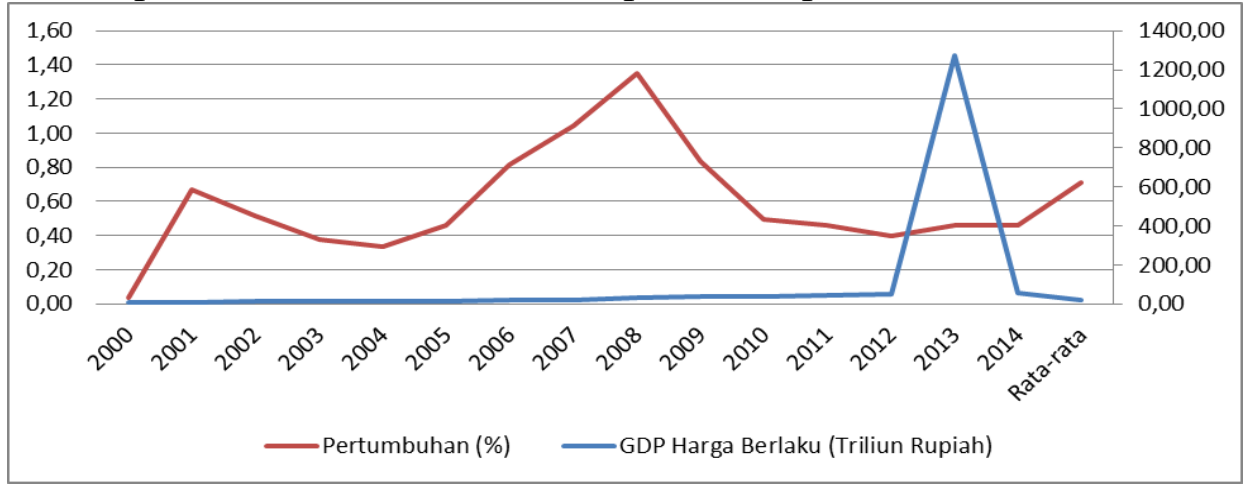

Sumber : ADB (Asian Development Bank)

Gambar 1 Perkembangan GDP Output sektor pertanian Indonesia

Dari data Gambar.1 terlihat bahwa selama periode tahun 1993-2014 rata-rata pertumbuhan output GDP sektor pertanian adalah $17 \%$ dengan nilai rata-ratanya adalah 496,9 triliun rupiah, dari tabel diatas terlihat bahwa selama periode tersebut nilai Output GDP sektor pertanian Indonesia mengalami fluktuasi atau naik turun dengan pertumbuhan terendah terjadi pada tahun 2000 yakni sebesar $0,50 \%$ dan pertumbuhan tertinggi terjadi pada tahun 1998 yakni sebesar 71,08\%.

\section{Perkembangan tenaga kerja sektor pertanian Indonesia}

Untuk mengetahui data perkembangan tenaga kerja Indonesia yang bekerja di sektor pertanian dapat dilihat pada tabel berikut ini :

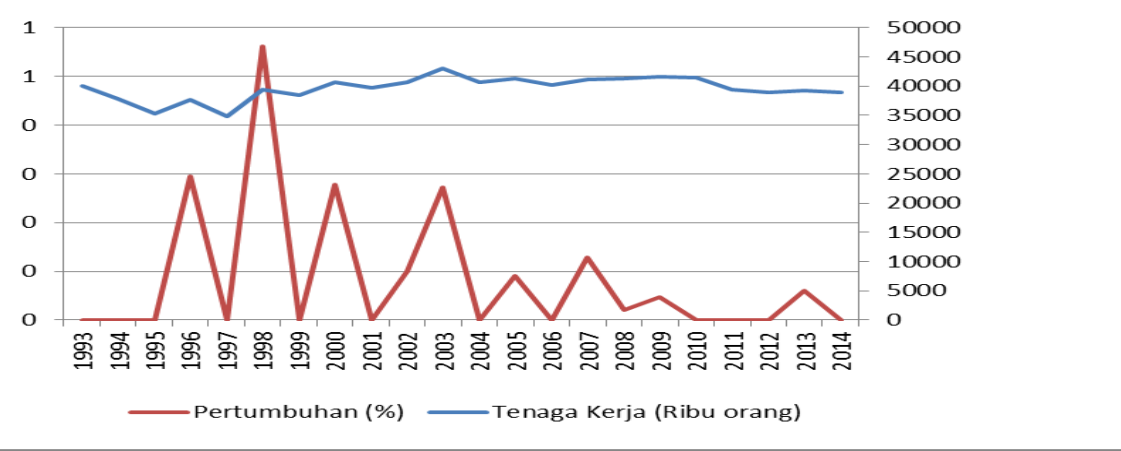

Sumber : ADB (Asian Development Bank)

Gambar 2 Perkembangan tenaga kerja Indonesia di sektor pertanian

Dari data Gambar.2 terlihat bahwa selama periode penelitian dari tahun 1993 2014 tenaga kerja yang bekerja di sektor pertanian di Indonesia kecenderungan data menunjukkan indikasi penurunan, hal ini tercermin dari nilai rata-rata pertumbuhannya yakni sebesar $-0.007 \%$,dengan nilai rata-rata sebesar 39.621,18 ribu orang, pertumbuhan tertinggi terjadi pada tahun 1998 yakni sebesar 13,29\% dan pertumbuhan terendah terjadi pada tahun 1997 yakni sebesar $-7.76 \%$. 


\section{Perkembangan konsumsi pemerintah Indonesia}

Untuk mengetahui data perkembangan konsumsi pemerintah Indonesia selama tahun

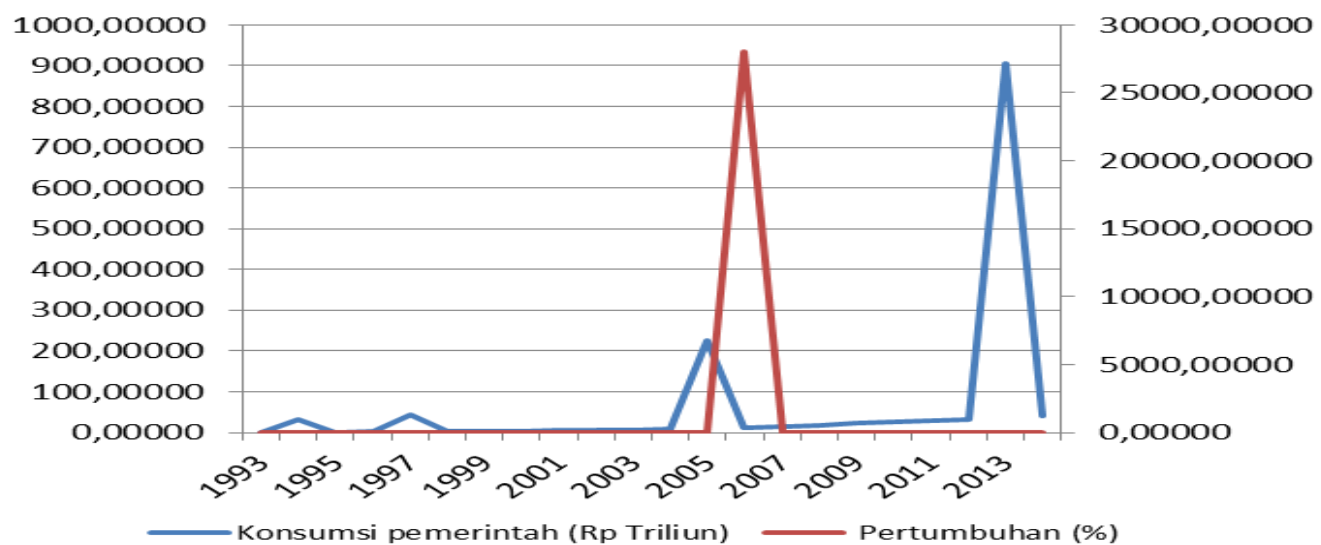

1993 - 2014 dapat dilihat pada tabel berikut ini :

Sumber : ADB (Asian Development Bank)

Gambar 3 Perkembangan Konsumsi pemerintah Indonesia

Dari data Gambar.3 terlihat bahwa pengeluaran konsumsi pemerintah Indonesia dari periode tahun 1993 - 2014 mengalami fluktuasi atau naik turun dengan nilai rata-rata sebesar 310,46 triliun rupiah dan rata-rata pertumbuhan sebesar $18,48 \%$, selama periode tersebut pertumbuhan tertinggi terjadi pada tahun 1999 yakni sebesar 33,45\% dan pertumbuhan terendah pada tahun 1994 yakni sebesar 4,02\%.

\section{Hasil regresi}

Untuk mengetahui Pengaruh GDP Output sektor pertanian terhadap konsumsi pemerintah dapat dilihat pada tabel berikut ini :

Tabel 1 Hasil regresi

\begin{tabular}{lrlrc}
\hline Variable & Coefficient & Std. Error & t-Statistic & Prob. \\
C & 229.7647 & 105.4428 & 2.179046 & 0.0421 \\
Tenaga_Kerja & -0.007118 & 0.002691 & -2.644606 & 0.0160 \\
GDP_Sektor_Pertanian & 0.729797 & 0.012416 & 58.77762 & 0.0000 \\
& & & & \\
\hline R-squared & 0.994745 & Mean dependent var & 310.0873 \\
Adjusted R-squared & 0.994192 & S.D. dependent var & 312.5635 \\
S.E. of regression & 23.82060 & Akaike info criterion & 9.305102 \\
Sum squared resid & 10780.99 & Schwarz criterion & 9.453881 \\
Log likelihood & -99.35612 & Hannan-Quinn criter. & 9.340150 \\
F-statistic & 1798.343 & Durbin-Watson stat & 0.779456 \\
Prob(F-statistic) & 0.000000 & & \\
\hline Sumber:Data diolat & & &
\end{tabular}

Sumber : Data diolah, 2017

Dari Gambar.1.hasil nilai t hitung 52,62 dengan probabilitas lebih kecil dari tingkat signifikansi alpha 1\% maka dapat diambil kesimpulan bahwa GDP Output sektor pertanian berpengaruh positif dan signifikan terhadap konsumsi pemerintah. Selanjutnya berdasarkan hasil regresi tentang pengaruh tenaga kerja sektor pertanian terhadap konsumsi pemerintah diperoleh persamaan regresi yakni : 
Konsumsi Pemerintah= 229.765 -0.0071 Tenaga Kerja + 0.729GDP SektoPertanian +e

Dari hasil persamaan tersebut dapat di interpretasikan bahwa pada saat tenaga kerja dan GDP output sektor pertanian dianggap tetap atau tidak berubah maka rata-rata nilai konsumsi pemerintah sebesar 229,765 triliun rupiah, jika terjadi kenaikan tenaga kerja sebesar 1 orang maka akan menyebabkan penurunan konsumsi pemerintah sebesar 0,0071 triliun rupiah. Sementara jika terjadi kenaikan GDP output sektor pertaniaan naik sebesar 1 triliun rupiah maka akan menyebabkan terjadinya kenaikan konsumsi pemerintah 0,72 triliun rupiah.

\section{KESIMPULAN DAN SARAN}

\section{Kesimpulan}

Selama periode tahun 1993 - 2014 rata-rata pertumbuhan output GDP sektor pertanian adalah $17 \%$ dengan nilai rata-ratanya adalah 496,9 triliun rupiah, dari tabel diatas terlihat bahwa selama periode tersebut nilai Output GDP sektor pertanian Indonesia mengalami fluktuasi atau naik turun dengan pertumbuhan terendah terjadi pada tahun 2000 yakni sebesar $0,50 \%$ dan pertumbuhan tertinggi terjadi pada tahun 1998 yakni sebesar 71,08\%. Untuk tenaga kerja sektor pertanian nilai rata-rata pertumbuhannya yakni sebesar $-0.007 \%$, dengan nilai rata-rata sebesar $39.621,18$ ribu orang, pertumbuhan tertinggi terjadi pada tahun 1998 yakni sebesar 13,29\% dan pertumbuhan terendah terjadi pada tahun 1997 yakni sebesar $-7.76 \%$. Sementara variabel konsumsi pemerintah dengan nilai rata-rata sebesar 310,46 triliun rupiah dan rata-rata pertumbuhan sebesar $18,48 \%$, selama periode tersebut pertumbuhan tertinggi terjadi pada tahun 1999 yakni sebesar 33,45\% dan pertumbuhan terendah pada tahun 1994 yakni sebesar 4,02\%. Hasil regresi menunjukkan bahwa variabel GDP Output sektor pertanian berpengaruh positif dan signifikan terhadap Konsumsi pemerintah, sementara variabel tenaga kerja sektor pertanian tidak berpengaruh signifikan terhadap konsumsi pemerintah.

\section{Saran}

Adapun rekomendasi atau saran yang dapat disampaikan dari hasil penelitian ini sebaiknya pemerintah terus berupaya meningkatkan produktifitas masyrakat disektor pertanian dengan meningkatkan kemampuan sumber daya manusia dan modal termasuk teknologi agar dapat membantu meningkatkan pendapatan pekerja di sektor pertanian sehingga membantu penyerapan tenaga kerja dan berkontribusi terhadap pendapatan nasional yang membantu pembiayaan konsumsi pemerintah. Hasil produksi dari sektor pertanian ternyata merupakan salah satu sumber yang dapat terus di optimalkan untuk menyumbang pendapatan nasional sehingga dapat mencukupi kebutuhan dalam negeri dan dapat membiayai pengeluaran konsumsi pemerintah.

\section{DAFTAR PUSTAKA}

Appleyard, Dennis.; Alfred J field.; Jr. Steven L Cobb.(2008).International Economics. 6th Edition. McGraww-Hill

Asian Development Bank.(2009). Key Indicators For Asia and Pasific 2008. Asian Development Bank Statistics.

Blanchard, Olivier.(2003). Macroeconomics.3rd Edition. Prentice-Hall.

Dornbusch,Rudiger.;Stanley,Fischer.;Richard,Startz.(2004).Macroeconomics. ${ }^{\text {th }}$ Edition . McGraww-Hill. 
Erfit.(2017).Pemanfaatan Dana Corporate Social Responsibility (CSR) Untuk Pembiayaan Pembangunan Pertanian di Provinsi Jambi. Jurnal Perspektif Pembiayaan dan Pembangunan Daerah, 4(3);143-154.

Euphrasia,Susy.;Suhendra.(2004). Peranan Sektor Pertanian Dalam Pertumbuhan Ekonomi di Indonesia Dengan Pendekatan Input-Output”.

Gaspersz, Vincent.(1997). Manajemen Kualitas Penerapan Konsep-Konsep Kualitas Dalam Manajemen Bisnis Total. Jakarta: PT. Gramedia Pustaka Utama

Gujarati,DamodarN.(2004).Basic Econometrics. 4th Edition. http://muslehgeo. blogspot.co.id /2013/06/teori-teori-ketenagakerjaan.html

Mangkoesoebroto, Guritno.(1994). Ekonomi Publik, BPFE : Yogyakarta

Mankiw, George N.(2001). Macroeconomics. 5th Edition. McGraw-Hill

Marius,Jelamu,Ardu.(2004).Memecahkan masalah Pengangguran di Indonesia. Makalah, IPB:Bogor

McGraw-Hill.(2008). International Financial Statistics. CD-ROM. IMF. 2008

Pitartono.(2012). Analisis Tingkat Pengangguran Di Jawa Tengah Tahun 1997-2013. Skripsi S1, Program Sarjana Fakultas Ekonomika dan Bisnis Universitas Diponegoro

Rahmadi,Selamet.;Parmadi.(2013).Analisis Pemetaan Kinerja Keuangan Kabupaten/ Kota Provinsi Jambi, Jurnal Paradigma Ekonomika, 1(7);42-56

Ropingi.;Dany Artanto.(2002). Peranan Sektor Pertanian dalam Pengembangan Perekonomian Wilayah Propinsi Jawa Tengah (Pendekatan Analisis Input Output).

Roy, Atrayee,Ghosh.;Hendrik.F, Van,Den,Berg. (2006). Foreign Direct Investment and Economics Growth: A Time-Series Approach. Global Economy Journal. 6(1); 119

Salvatore, Dominic. (2007). International Economics. Prentice-Hall.

Suparmoko. (2001). Ekonomi Publik Untuk Keuangan dan Pembangunan Daerah, BPFE: Yogyakarta.

Syaifuddin.;Adi Bhakti.;Rahma Nurjanah.(2017).Dampak Peningkatan Pengeluaran Konsumsi Sektor Rumah Tangga Dan Pengeluaran Sektor Pemerintah Terhadap Pertumbuhan Ekonomi Di Propinsi Jambi. Jurnal Sains Sosio Humaniora. 1(1); 66-78. 